\title{
Cobalt-lanthanum catalyst precursors for ammonia synthesis: determination of calcination temperature and storage conditions
}

\author{
Magdalena Zybert $^{1 *}$, Aleksandra Tarka ${ }^{1}$, Bogusław Mierzwa ${ }^{2}$, Wioletta Raróg-Pilecka ${ }^{1}$ \\ ${ }^{1}$ Warsaw University of Technology, Faculty of Chemistry, Noakowskiego 3, 00-664 Warsaw, Poland \\ ${ }^{2}$ Institute of Physical Chemistry, Polish Academy of Sciences, Kasprzaka 44/52, 01-224 Warsaw, Poland \\ *corresponding author: mzybert@ch.pw.edu.pl
}

\begin{abstract}
A thermal decomposition of a cobalt-lanthanum catalyst precursor containing a mixture of cobalt and lanthanum compounds obtained by co-precipitation were studied using thermal analysis coupled with mass spectrometry (TG-MS). Studies revealed that the calcination in air at $500^{\circ} \mathrm{C}$ is sufficient to transform the obtained cobalt precipitate into $\mathrm{Co}_{3} \mathrm{O}_{4}$, but it leads to only partial decomposition of lanthanum precipitate. In order to obtain $\mathrm{Co} / \mathrm{La}$ catalyst precursor containing $\mathrm{La}_{2} \mathrm{O}_{3}$ the calcination in air at the temperature about $800^{\circ} \mathrm{C}$ is required. However, it is unfavorable from the point of view of textural properties of the catalyst precursor. A strong effect of storage conditions on the phase composition of the studied cobalt-lanthanum catalyst precursor, caused by the formation of lanthanum hydroxide and lanthanum carbonates from $\mathrm{La}_{2} \mathrm{O}_{3}$ when contacting with air, was observed.
\end{abstract}

Keywords: ammonia synthesis, catalyst precursor, cobalt, lanthanum, thermal analysis.

\section{INTRODUCTION}

In the literature cobalt catalysts are known as active systems for low-temperature $\mathrm{NH}_{3}$ synthesis process ${ }^{1-9}$, in particular when they are promoted with barium ${ }^{3-5}$ or selected rare earth metals (cerium ${ }^{6,7}$ or lanthanum ${ }^{8,9}$ ). However, a preparation and subsequent application of catalytic materials containing lanthanum require a special attention. Lanthanum oxide exhibits a strong tendency to interact with $\mathrm{H}_{2} \mathrm{O}$ and $\mathrm{CO}_{2}$ present in air, which may have a significant impact on the phase composition and properties of $\mathrm{La}_{2} \mathrm{O}_{3}{ }^{10}$ and consequently also on the properties of the catalyst containing lanthanum oxide as an important component. A preparation method used (a type of lanthanum oxide precursor and its decomposition conditions) $)^{\mathbf{1 0 - 1 7}}$ is also of great significance in this case. Hence, two important issues are necessary to be considered during a development of catalytic systems with lanthanum oxide. Firstly, a temperature of catalyst precursor calcination - it should be selected properly in order to obtain a material containing desired components and having optimal textural properties at the same time. Secondly, a possible change of a catalytic material composition caused by the interaction of $\mathrm{La}_{2} \mathrm{O}_{3}$ with $\mathrm{H}_{2} \mathrm{O}$ and $\mathrm{CO}_{2}$ contained in air, what can significantly modify final properties of the studied catalyst.

Because of its wide application potential thermal analysis is a useful tool in the investigation of properties of catalytic materials ${ }^{18-21}$. In our previous paper ${ }^{22}$ it has been successfully applied to determine the composition of catalyst precursors containing cobalt and cerium or cobalt and lanthanum. Moreover, it is possible to simulate industrial operation conditions of catalysts (high temperature, atmosphere of various composition and properties - oxidizing, reducing) in a furnace of a thermobalance. This allows studies of many crucial catalyst properties, e.g. a course of catalyst reduction ${ }^{6-9,23}$ or methanation process of activated carbons ${ }^{5}$ used as a catalyst support.

In the present work we used a thermal analysis coupled with mass spectrometry (TG-MS) to determine the appropriate calcination temperature of cobalt-lanthanum catalyst precursor obtained by co-precipitation and indicate the influence of conditions, in which such a catalytic material is stored, on its composition. These are essentials information, both from the point of view of future practical use of catalysts containing lanthanum oxide and precise analysis of their characterization studies results, in particular those carried out using ex situ techniques.

\section{EXPERIMENTAL DETAILS}

\section{Preparation of catalysts precursors}

A precipitate containing cobalt compounds, a precipitate containing lanthanum compounds and a co-precipitated mixture of cobalt and lanthanum compounds in fixed proportions were obtained by precipitation/co-precipitation ${ }^{8}$, respectively, using $\mathrm{K}_{2} \mathrm{CO}_{3}$ as the precipitating agent. An appropriate amount of $\mathrm{Co}\left(\mathrm{NO}_{3}\right)_{2} \cdot 6 \mathrm{H}_{2} \mathrm{O}$ or $\mathrm{La}\left(\mathrm{NO}_{3}\right)_{3} \cdot 6 \mathrm{H}_{2} \mathrm{O}$ or a mixture of $\mathrm{Co}\left(\mathrm{NO}_{3}\right)_{2} \cdot 6 \mathrm{H}_{2} \mathrm{O}$ and $\mathrm{La}\left(\mathrm{NO}_{3}\right)_{3} \cdot 6 \mathrm{H}_{2} \mathrm{O}$ were dissolved in distilled water and warmed to approximately $90^{\circ} \mathrm{C}$. Then, a warm solution of $\mathrm{K}_{2} \mathrm{CO}_{3}$ was slowly added. The obtained precipitates were filtered under reduced pressure (about $0.04 \mathrm{MPa}$ ), washed with cold distilled water until $\mathrm{pH}$ was neutral and dried $\left(120^{\circ} \mathrm{C}\right.$, overnight $)$. For the calcination studies the precipitates as-prepared were used. While for the storage condition studies the co-precipitated mixture containing cobalt and lanthanum compounds was calcined at $500^{\circ} \mathrm{C}(\mathrm{Co} / \mathrm{La}(7.4)$ sample $)$ and then divided into two parts. One of them was stored in a close vessel for 8 months. The second part of the sample was stored in an open vessel for 8 months in the contact with air. All the obtained materials and their pretreatment conditions are listed in Table 1.

\section{EXPERIMENTAL METHODS}

Thermogravimetric studies were performed using Netzsch STA449C thermobalance equipped with a quadrupole mass spectrometer Netzsch QMS 403C. Two types of experiments were conducted (Table 1):

Experiment 1 - the precipitate containing cobalt compounds, the precipitate containing lanthanum compounds and the co-precipitated mixture of cobalt and 
Table 1. Experimental conditions and materials used for TG-MS measurements

\begin{tabular}{|c|c|c|c|}
\hline & Material used & Pretreatment conditions & Type of TG-MS experiment \\
\hline \multirow{3}{*}{$\begin{array}{l}\text { Calcination } \\
\text { studies }\end{array}$} & $\begin{array}{l}\text { precipitate containing Co } \\
\text { compounds }\end{array}$ & as-prepared & \multirow{3}{*}{$\begin{array}{l}\text { Experiment } 1 \\
90 \% \text { air/argon } \\
\text { flow } 100 \mathrm{~mL} / \mathrm{min} \\
\text { heating rate: } 10^{\circ} / \mathrm{min} \\
\text { heating to } 500^{\circ} \mathrm{C} \rightarrow \text { isotherm } 500^{\circ} \mathrm{C}(1 \mathrm{~h}) \rightarrow \\
\text { heating to } 800^{\circ} \mathrm{C} \rightarrow \text { isotherm } 800^{\circ} \mathrm{C}(1 \mathrm{~h}) \rightarrow \\
\text { heating to } 1100^{\circ} \mathrm{C}\end{array}$} \\
\hline & $\begin{array}{l}\text { precipitate containing La } \\
\text { compounds }\end{array}$ & as-prepared & \\
\hline & $\begin{array}{l}\text { co-precipitated mixture } \\
\text { containing Co and La } \\
\text { compounds }\end{array}$ & as-prepared & \\
\hline \multirow{3}{*}{$\begin{array}{l}\text { Storage } \\
\text { conditions } \\
\text { studies }\end{array}$} & \multirow{3}{*}{$\mathrm{Co} / \mathrm{La}(7.4)^{\mathrm{a}}$} & $\begin{array}{l}\text { calcined at } 500^{\circ} \mathrm{C}(16 \mathrm{~h}) \text { in air (the } \\
\text { reference material) }\end{array}$ & \multirow{3}{*}{$\begin{array}{l}\text { Experiment } 2 \\
\text { argon } \\
\text { flow } 100 \mathrm{~mL} / \mathrm{min} \\
\text { heating rate: } 10^{\circ} / \mathrm{min} \\
\text { heating from room temperature to } 1100^{\circ} \mathrm{C}\end{array}$} \\
\hline & & $\begin{array}{l}\text { calcined at } 500^{\circ} \mathrm{C}(16 \mathrm{~h}) \text { in air, stored in a } \\
\text { closed vessel ( } 8 \text { months) }\end{array}$ & \\
\hline & & $\begin{array}{l}\text { calcined at } 500^{\circ} \mathrm{C}(16 \mathrm{~h}) \text { in air, stored in } \\
\text { an open vessel in the contact with air ( } 8 \\
\text { months) }\end{array}$ & \\
\hline
\end{tabular}

${ }^{a}$ La content (7.4 wt.\%) determined by inductively coupled plasma optical emission spectroscopy (ICP-OES)

lanthanum compounds were heated gradually from room temperature up to $1100^{\circ} \mathrm{C}$ at the constant rate of $10^{\circ} \mathrm{C} / \mathrm{min}$. The temperature was raised to $500^{\circ} \mathrm{C}$ and then maintained for 1 hour (isothermal step 1). In the next step the temperature was increased to $800^{\circ} \mathrm{C}$ and maintained for 1 hour (isothermal step 2). In a final step the sample was heated to $1100^{\circ} \mathrm{C}$. The system was supplied with $90 \%$ air/Ar mixture (flow $100 \mathrm{~mL} / \mathrm{min}$ ). The mass change, temperature and selected $\mathrm{m} / \mathrm{e}$ signals $\left(\mathrm{H}_{2} \mathrm{O}, \mathrm{CO}_{2}, \mathrm{CO}, \mathrm{NO}, \mathrm{NO}_{2}\right)$ were monitored throughout the entire measurement.

Experiment 2 - samples of cobalt-lanthanum catalyst precursor $\mathrm{Co} / \mathrm{La}(7.4)$ (i.e. the material obtained after calcination of the co-precipitated mixture of cobalt and lanthanum compounds in air at $500^{\circ} \mathrm{C}$ ), differing in the storage method (in a close vessel for 8 months from a preparation or in an open vessel for 8 months from a preparation) were heated from room temperature up to $1100^{\circ} \mathrm{C}$ at the constant rate of $10^{\circ} \mathrm{C} / \mathrm{min}$ in a pure ( $\geq 99.999 \mathrm{vol} \%$ ) argon constant flow $(100 \mathrm{~mL} / \mathrm{min})$. The mass change, temperature, $\mathrm{H}_{2} \mathrm{O}$ and $\mathrm{CO}_{2}$ mass signals were monitored. The measurement was performed also for the studied cobalt-lanthanum catalyst precursor $\mathrm{Co} /$ $\mathrm{La}(7.4)$ immediately after preparation (the reference material).

During all experiments samples of approximately $15 \mathrm{mg}$ were used. The reference crucible was empty. In order to avoid water physisorption all the necessary apparatus parts were kept heated to $250^{\circ} \mathrm{C}$. The data analysis was carried out using Proteus Software (Netzsch).

A phase composition of the samples obtained (i.e. precipitates prior to heat treatment, as well as the precipitate containing La compounds after calcination in air $\left(500^{\circ} \mathrm{C}\right.$ or $\left.800^{\circ} \mathrm{C}\right)$ were determined using X-ray powder diffraction studies. Data were collected with a Rigaku-Denki (Geigerflex) diffractometer in a Bragg-Brentano configuration using a $\mathrm{Cu}$-sealed tube operating at $40 \mathrm{kV}$ and $40 \mathrm{~mA}$ with the stability of $0.01 \% / 8$ hours. Measurements of each system were performed in the scattering $2 \Theta$ range of $15^{\circ}$ to $100^{\circ}$ with a $0.02^{\circ}$ step and a counting rate $6 \mathrm{~s} / \mathrm{step}$.

The textural parameters of the studied catalyst precursors were measured using a nitrogen physisorption technique with ASAP2020 instrument (Micromeritics). Prior to measurements samples were degassed (1 hour at $90^{\circ} \mathrm{C}$ and next 4 hours at $200^{\circ} \mathrm{C}$ ). BET isotherm equation was used to determine the total surface area, whereas the total pore volume was estimated based on $\mathrm{BJH}$ isotherm equation.

\section{RESULTS AND DISCUSSION}

\section{Calcination studies}

In order to determine the changes during calcination in air, the obtained precipitates were subjected to a thermal decomposition. Thermal analysis coupled with mass spectrometry allowed to simulate the real conditions during the calcination of the obtained samples in the furnace at temperatures up to $1100^{\circ} \mathrm{C}$. However, the special attention was focused on the stages of annealing the samples at $500^{\circ} \mathrm{C}$ (isothermal step 1) and $800^{\circ} \mathrm{C}$ (isothermal step 2).

Figure 1 presents the results of the thermal decomposition of the precipitate containing cobalt compounds. In the initial step of a mass loss (about $100^{\circ} \mathrm{C}$ ) a small

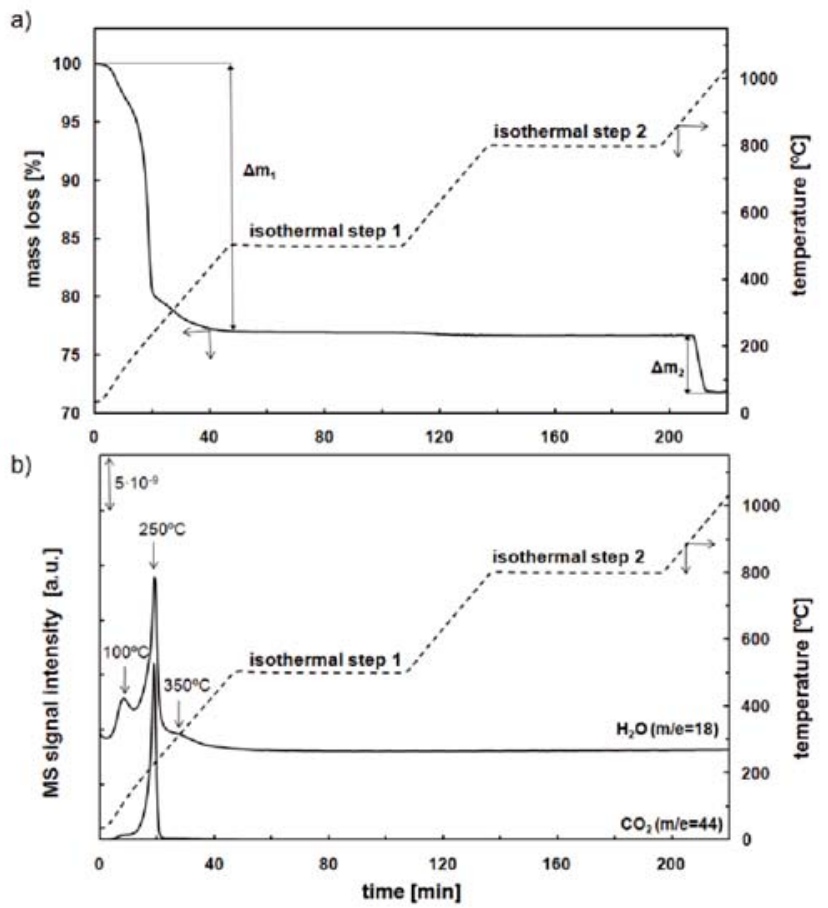

Figure 1. TG-MS calcination studies of the precipitate containing Co compounds: (a) mass loss, (b) mass signals of $\mathrm{H}_{2} \mathrm{O}(\mathrm{m} / \mathrm{e}=18)$ and $\mathrm{CO}_{2}(\mathrm{~m} / \mathrm{e}=44)$ 
peak on the mass signal of $\mathrm{H}_{2} \mathrm{O}(\mathrm{m} / \mathrm{e}=18)$ and a slight signal of $\mathrm{CO}_{2}(\mathrm{~m} / \mathrm{e}=44)$ are visible, which correspond to desorption of water and carbon dioxide from the sample surface. With increasing temperature a significant mass loss $\left(\Delta \mathrm{m}_{1}\right)$, accompanied by the intensive peaks on $\mathrm{H}_{2} \mathrm{O}$ and $\mathrm{CO}_{2}$ mass signals with maxima at $250^{\circ} \mathrm{C}$ and $350^{\circ} \mathrm{C}$, respectively, were observed. This indicates that during the precipitation process hydrated cobalt hydroxycarbonate of indefinite composition $\left(\mathrm{Co}_{\mathrm{x}}(\mathrm{OH})_{\mathrm{y}}\left(\mathrm{CO}_{3}\right)_{\mathrm{z}} \cdot \mathrm{nH}_{2} \mathrm{O}\right)$ may be obtained, which is confirmed by the XRPD measurements results. In the diffraction pattern of the precipitated sample (Fig. 2) signals corresponding to $\mathrm{Co}\left(\mathrm{CO}_{3}\right)_{0.5}(\mathrm{OH}) \cdot 0.11 \mathrm{H}_{2} \mathrm{O}($ JCPDS $48-0083)$ were observed. This phase decomposes to $\mathrm{Co}_{3} \mathrm{O}_{4}$ when temperature increases to $500^{\circ} \mathrm{C}$. When the sample was annealed at $500^{\circ} \mathrm{C}$ (isothermal step 1), no mass loss on the TG curve, as well as no signals of released gases were recorded. Changes of TG curve did not occur also during further heating of the sample up to $800^{\circ} \mathrm{C}$ and its annealing at this temperature (isothermal step 2). The second mass loss $\left(\Delta \mathrm{m}_{2}\right)$, visible in the temperature range of $890-980^{\circ} \mathrm{C}$, corresponds to the conversion of $\mathrm{Co}_{3} \mathrm{O}_{4}$ to $\mathrm{CoO}^{24,25}$, according to Eq. (1):

$2 \mathrm{Co}_{3} \mathrm{O}_{4} \rightarrow 6 \mathrm{CoO}+\mathrm{O}_{2}$

Further heating of this material up to $1100^{\circ} \mathrm{C}$ did not result in any other changes in the TG curve. The presented results clearly revealed that the calcination at $500^{\circ} \mathrm{C}$ is sufficient to transform the obtained hydrated cobalt hydroxycarbonate into cobalt oxide $\left(\mathrm{Co}_{3} \mathrm{O}_{4}\right)$.

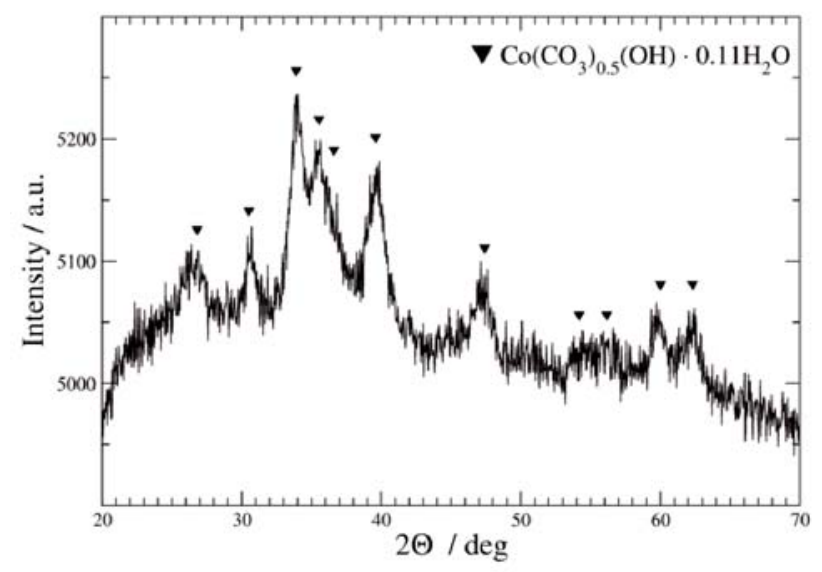

Figure 2. XRPD pattern of the precipitate containing Co compounds (prior to heat treatment)

The course of thermal decomposition of the obtained precipitate containing La compounds is presented in Figure 3. Initially a small peak on the mass signal of $\mathrm{H}_{2} \mathrm{O}$ $(\mathrm{m} / \mathrm{e}=18)$ is visible, which corresponds to desorption of water from the sample surface. During heating the sample to the temperature of $500^{\circ} \mathrm{C}$ a substantial mass loss $\left(\Delta \mathrm{m}_{1}\right)$ was observed accompanied by intensive peaks on $\mathrm{H}_{2} \mathrm{O}$ mass signals (with maxima at about $200^{\circ} \mathrm{C}, 350^{\circ} \mathrm{C}$, $450^{\circ} \mathrm{C}$ ) and $\mathrm{CO}_{2}$ mass signals (with maxima at about $350^{\circ} \mathrm{C}, 450^{\circ} \mathrm{C}$ ). This indicates that during the preparation process lanthanum carbonate hydrate $\left(\mathrm{La}_{2}\left(\mathrm{CO}_{3}\right)_{3} \cdot \mathrm{xH}_{2} \mathrm{O}\right)$ and lanthanum carbonate hydroxide $\left(\mathrm{LaCO}_{3} \mathrm{OH}\right)$ may be obtained. The presence of this later phase was indicated in the XRPD pattern (JCPDS 49-0981) - Figure 4. However, heating the sample to $500^{\circ} \mathrm{C}$ lead to its dehydration and dehydroxylation, visible as peaks on the $\mathrm{m} / \mathrm{e}=18$

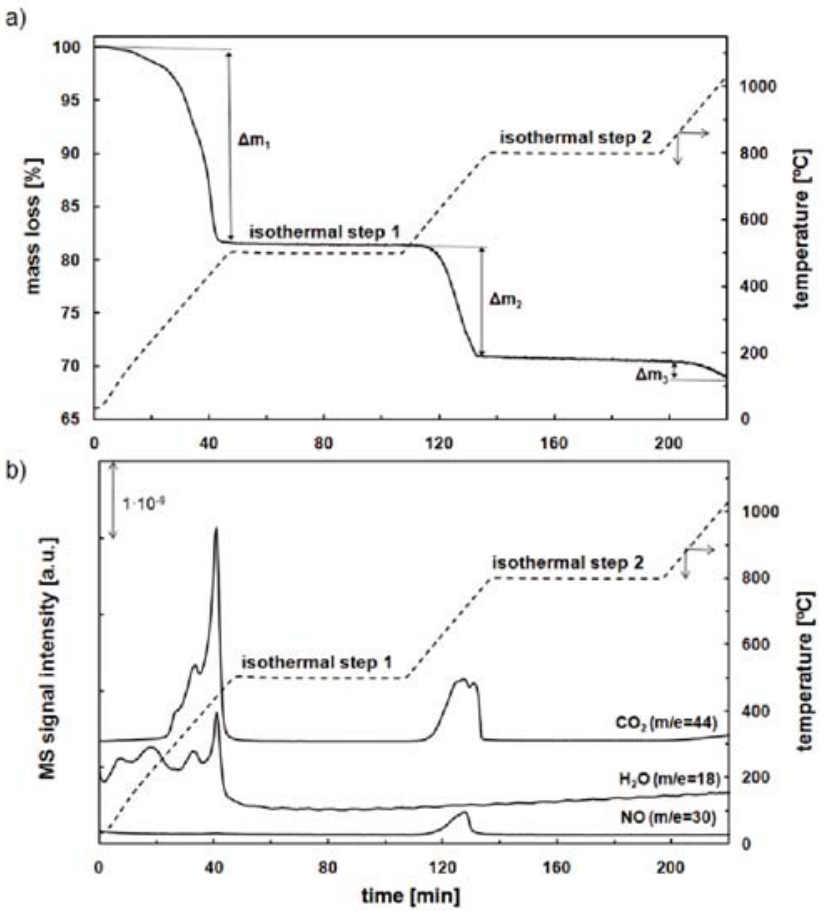

Figure 3. TG-MS calcination studies of the precipitate containing La compounds: (a) mass loss, (b) mass signals of $\mathrm{H}_{2} \mathrm{O}(\mathrm{m} / \mathrm{e}=18), \mathrm{CO}_{2}(\mathrm{~m} / \mathrm{e}=44)$ and $\mathrm{NO}(\mathrm{m} / \mathrm{e}$ $=30$ )

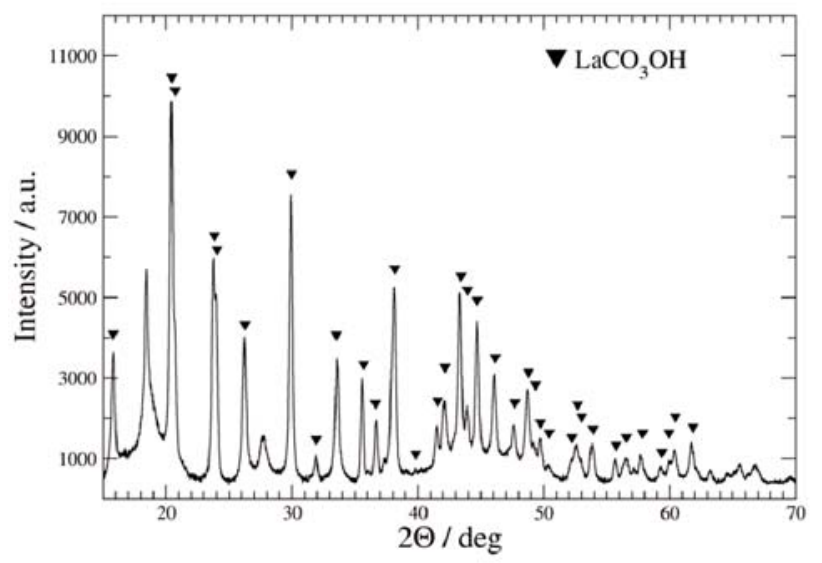

Figure 4. XRPD pattern of the precipitate containing La compounds (prior to heat treatment)

mass signal. The resulting lanthanum carbonate further decomposes to lanthanum dioxycarbonate (peaks on the $\mathrm{m} / \mathrm{e}=44$ mass signal), according to Eq. (2):

$\mathrm{La}_{2}\left(\mathrm{CO}_{3}\right)_{3}=\mathrm{La}_{2} \mathrm{O}_{2} \mathrm{CO}_{3}+2 \mathrm{CO}_{2}$

This observation is confirmed by the diffraction pattern of the sample after its calcination at $500^{\circ} \mathrm{C}$ (Fig. 5), where signals derived from $\mathrm{La}_{2} \mathrm{O}_{2} \mathrm{CO}_{3}$ phase are clearly visible. This is in good agreement with the literature ${ }^{\mathbf{1 0}}, \mathbf{1 4}^{4}$, which indicates that a thermal decomposition of lanthanum carbonate is a complex process and occurs with the formation of a stable intermediate product $\left(\mathrm{La}_{2} \mathrm{O}_{2} \mathrm{CO}_{3}\right)$. This compound, in turn, decomposes to lanthanum oxide at higher temperatures. During the conducted TG-MS experiment (Fig. 3) a decomposition of $\mathrm{La}_{2} \mathrm{O}_{2} \mathrm{CO}_{3}$ to $\mathrm{La}_{2} \mathrm{O}_{3}$ occurred at two stages: when temperature increased in the range $500-800^{\circ} \mathrm{C}$ (the mass loss $\Delta \mathrm{m}_{2}$ and the corresponding peak on the $\mathrm{m} / \mathrm{e}=44$ mass signal were observed) and in the range of $800-1100^{\circ} \mathrm{C}$, as it is confirmed by a small mass loss $\left(\Delta \mathrm{m}_{3}\right)$ and a slight raise 
of the $\mathrm{m} / \mathrm{e}=44$ mass signal (Fig. $3 \mathrm{~b}$ ). The decomposition of dioxycarbonate phase occurs according to the general Eq. (3):

$\mathrm{La}_{2} \mathrm{O}_{2} \mathrm{CO}_{3}=\mathrm{La}_{2} \mathrm{O}_{3}+\mathrm{CO}_{2}$

Moreover, the observed mass loss $\left(\Delta \mathrm{m}_{2}+\Delta \mathrm{m}_{3}\right.$, about $12 \%$ ) connected with the release of $\mathrm{CO}_{2}$ corresponds well with the theoretical mass loss resulting from the Eq. (3). In addition, a small peak derived from $\mathrm{NO}(\mathrm{m} / \mathrm{e}=30)$ was also visible at the temperature above $500^{\circ} \mathrm{C}$. This is most likely the effect of a decomposition of lanthanum nitrate residues (in the form of $\left.\mathrm{LaONO}_{3}\right)^{10,26}$, which was used during the precipitation process. Based on the presented results it can be stated that in order to obtain lanthanum oxide the calcination of the obtained lanthanum precipitate in air at temperature about $800^{\circ} \mathrm{C}$ is required. XRPD analysis (Fig. 5) confirms these observations - the diffraction pattern of the sample obtained after its calcination at $800^{\circ} \mathrm{C}$ indicates the presence of $\mathrm{La}_{2} \mathrm{O}_{3}$ phase only.

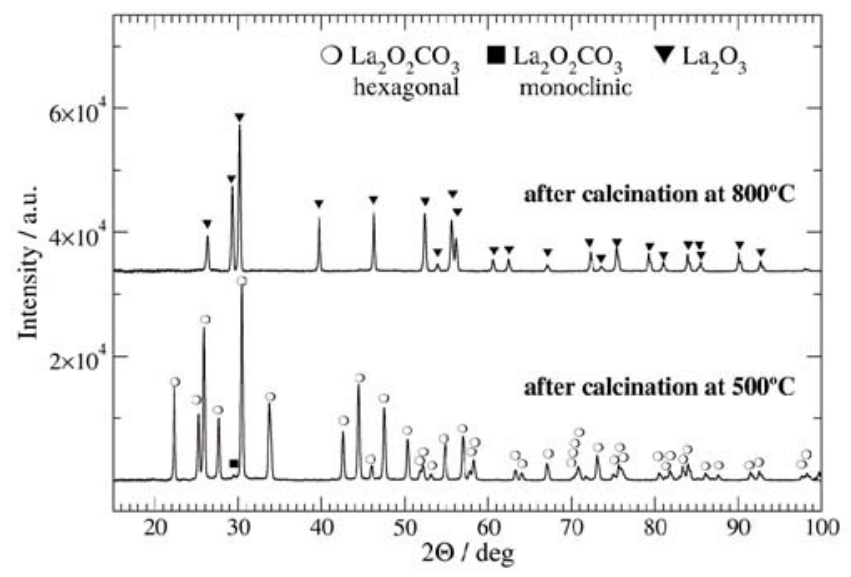

Figure 5. XRPD patterns of the precipitate containing La compounds after calcination in air at $500^{\circ} \mathrm{C}$ or $800^{\circ} \mathrm{C}$

Due to a poorly organized (nearly amorphous) structure of the co-precipitated mixture containing Co and La compounds a determination of its phase composition by XRPD was impossible. Nevertheless, during the calcination of this sample - Figure 6, the same effects that were observed during the decomposition of the component materials, i.e. precipitate containing Co compound (Fig. 1) and precipitate containing La compound (Fig. 3), occurred. Three stages of decomposition of this mixture are clearly visible. The first stage (up to $500^{\circ} \mathrm{C}$ ) with a mass loss $\Delta \mathrm{m}_{1}$ and the evolution of $\mathrm{H}_{2} \mathrm{O}(\mathrm{m} / \mathrm{e}=18)$ and $\mathrm{CO}_{2}(\mathrm{~m} / \mathrm{e}=44)$ is associated with a dehydration and decomposition of cobalt precipitate and a partial decomposition of lanthanum precipitate. The second stage $\left(\Delta \mathrm{m}_{2}\right.$ and a slight raise on the $\mathrm{m} / \mathrm{e}=44$ signal $)$ occurred in the temperature range of $500-800^{\circ} \mathrm{C}$ and is connected to a further decomposition of $\mathrm{La}_{2} \mathrm{O}_{2} \mathrm{CO}_{3}$ to $\mathrm{La}_{2} \mathrm{O}_{3}$. The last stage $\left(\Delta \mathrm{m}_{3}\right)$ at temperatures above $800^{\circ} \mathrm{C}$ is a result of $\mathrm{Co}_{3} \mathrm{O}_{4} \rightarrow \mathrm{CoO}$ conversion, as described above.

Summing up this part of research it should be stated that a precursor of a cobalt-lanthanum catalyst obtained by calcination of a co-precipitated mixture of cobalt and lanthanum compounds at $500^{\circ} \mathrm{C}$ may consist of $\mathrm{Co}_{3} \mathrm{O}_{4}$, $\mathrm{La}_{2} \mathrm{O}_{3}$ and $\mathrm{La}_{2} \mathrm{O}_{2} \mathrm{CO}_{3}$. The formation of lanthanum cobaltite $\left(\mathrm{LaCoO}_{3}\right)$ is also possible as a result of the

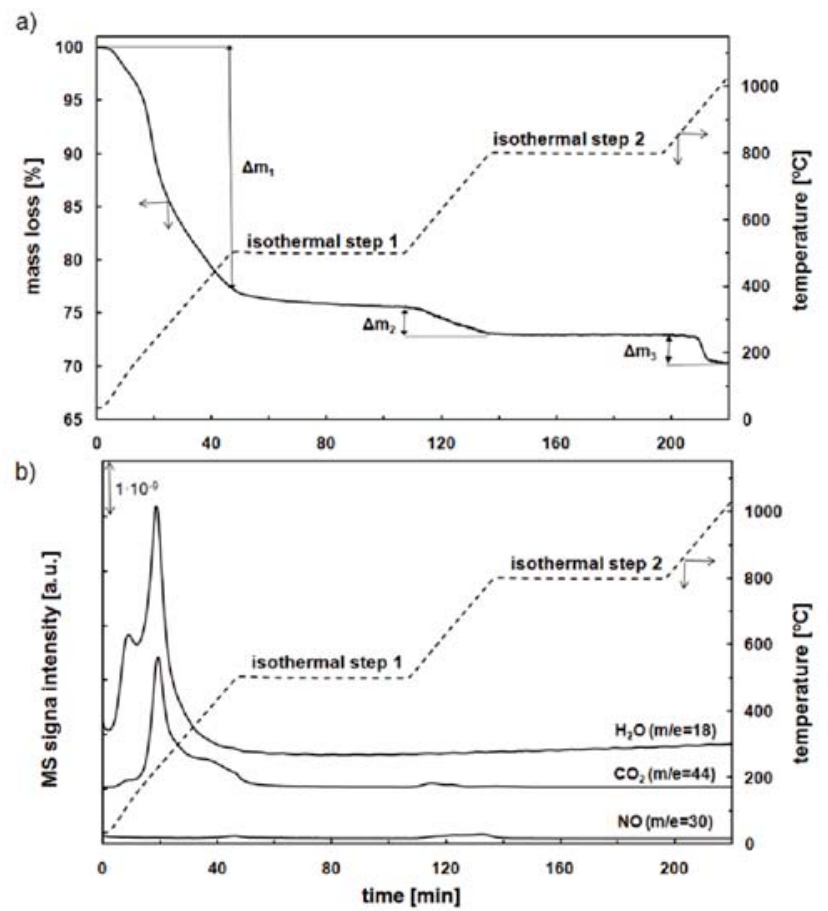

Figure 6. TG-MS calcination studies of the co-precipitated mixture containing Co and La compounds: (a) mass loss, (b) mass signals of $\mathrm{H}_{2} \mathrm{O}(\mathrm{m} / \mathrm{e}=18), \mathrm{CO}_{2}(\mathrm{~m} / \mathrm{e}$ $=44)$ and $\mathrm{NO}(\mathrm{m} / \mathrm{e}=30)$

interaction of main components of the studied catalyst precursor under preparation conditions. This effect was observed in our previous studies of $\mathrm{Co} / \mathrm{La} / \mathrm{Ba}$ catalysts ${ }^{9}, 28$. The diffraction patterns of the cobalt-lanthanum catalysts precursors presented in the paper ${ }^{9}$ clearly indicate that when the lanthanum content is properly high in relation to cobalt content, the $\mathrm{LaCoO}_{3}$ phase is formed. The preparation of $\mathrm{Co} / \mathrm{La}$ catalyst precursor containing $\mathrm{Co}_{3} \mathrm{O}_{4}$ and $\mathrm{La}_{2} \mathrm{O}_{3}$ oxides requires the use of higher calcination temperature (about $800^{\circ} \mathrm{C}$ ). However, it is unfavorable from the point of view of textural properties of the catalyst precursor. In fact, high-temperature calcination led to an undesirable effect of lowering a surface area and porosity of a catalyst precursor (see Table 2), which may influence significantly properties of a final catalyst ${ }^{27,28}$.

Table 2. Textural parameters of the studied $\mathrm{Co} / \mathrm{La}$ catalyst precursor after calcination at different temperatures

\begin{tabular}{|l|c|c|}
\hline $\begin{array}{l}\text { Calcination } \\
\text { temperature }\left[{ }^{\circ} \mathrm{C}\right]\end{array}$ & $\begin{array}{c}\text { Total surface area } \\
{\left[\mathrm{m}^{2} / \mathrm{g}\right]^{\mathrm{a}}}\end{array}$ & $\begin{array}{c}\text { Total pore volume } \\
{\left[\mathrm{cm}^{3} / \mathrm{g}\right]^{\mathrm{b}}}\end{array}$ \\
\hline 500 & 51.7 & 0.26 \\
\hline 800 & 3.2 & 0.01 \\
\hline
\end{tabular}

${ }^{a}$ total surface area determined on the basis of BET adsorption isotherm,

${ }^{\mathrm{b}}$ total pore volume determined on the basis of BJH adsorption isotherm.

The effect of storage conditions on the composition of the cobalt-lanthanum catalyst precursor

It is well know that lanthanum oxide is a highly hygroscopic compound and its easy interaction with $\mathrm{H}_{2} \mathrm{O}$ and atmospheric $\mathrm{CO}_{2}$ may affect significantly the phase composition of such a material (by creating hydroxides and carbonates) $)^{\mathbf{1 0}, \mathbf{1 1}, \mathbf{1 4}}$. Hence, storage conditions of lanthanum oxide are an essential factor influencing its properties and consequently the properties of catalysts, in which $\mathrm{La}_{2} \mathrm{O}_{3}$ is an important component. In order 

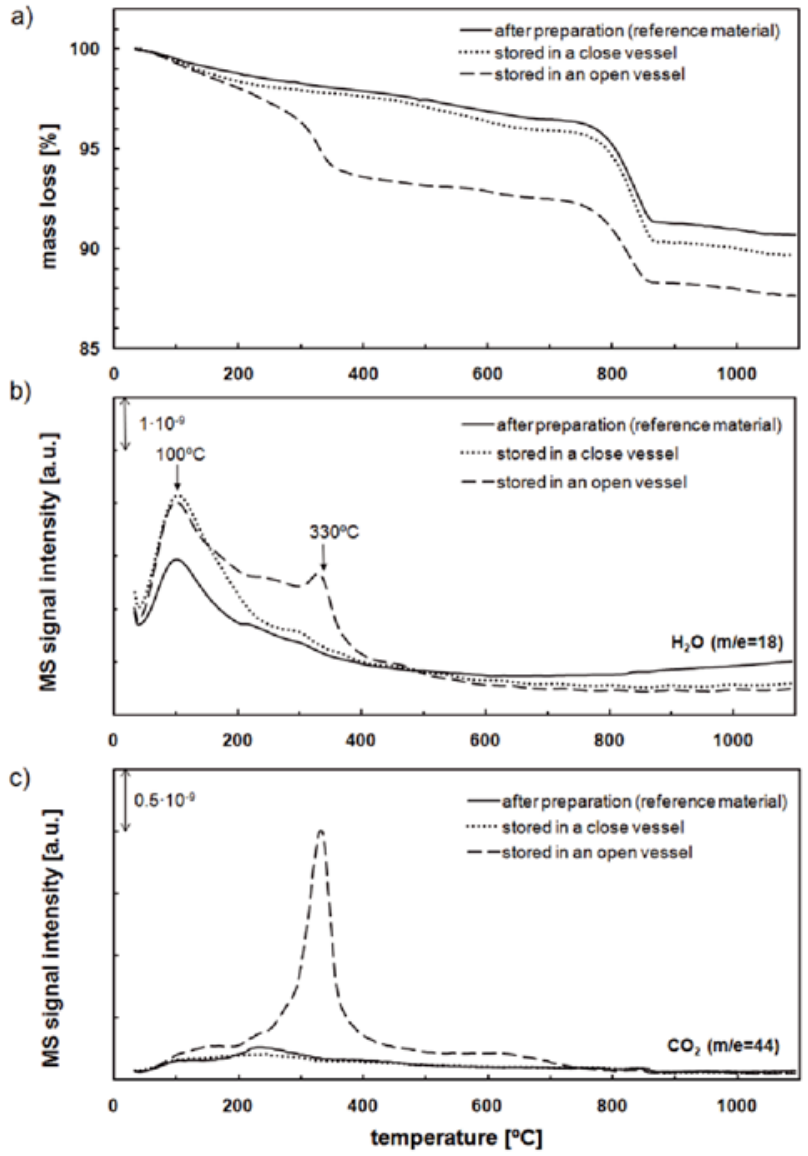

Figure 7. TG-MS studies of $\mathrm{Co} / \mathrm{La}(7.4)$ catalyst precursor samples stored in different conditions: (a) mass loss, (b) mass signals of $\mathrm{H}_{2} \mathrm{O}(\mathrm{m} / \mathrm{e}=18)$, (c) mass signals of $\mathrm{CO}_{2}(\mathrm{~m} / \mathrm{e}=44)$

to determine the effect of the storage method on the composition of the cobalt-lanthanum catalyst precursor TG-MS studies were performed for $\mathrm{Co} / \mathrm{La}(7.4)$ samples calcined at $500^{\circ} \mathrm{C}$, but differing in storage conditions: in a close vessel for 8 months (after preparation) or in an open vessel for 8 months (after preparation). The obtained results were compared with those for the reference material, i.e. for the $\mathrm{Co} / \mathrm{La}(7.4)$ catalyst precursor sample studied immediately after preparation (Fig. 7). For the reference material the initial slight mass loss (approx. $1.5 \%$ ) was observed (Fig. 7a), associated with a $\mathrm{H}_{2} \mathrm{O}$ desorption visible as a peak with a maximum at approx. $100^{\circ} \mathrm{C}$ on the $\mathrm{m} / \mathrm{e}=18$ mass signal (Fig. $\left.7 \mathrm{~b}\right)$. For the material stored for 8 months in a close vessel a slightly larger initial mass loss (approx. 2\%) appeared. It was accompanied by an increasing intensity of a signal of water desorbing from the sample surface at low temperatures $\left(100^{\circ} \mathrm{C}\right)$. No pronounced signal of $\mathrm{m} / \mathrm{e}=44$ was recorded (Fig. 7c) for these samples. For the material stored for 8 months in an open vessel (when contacting with air), the intensive desorption of $\mathrm{H}_{2} \mathrm{O}$ was observed at temperature approx. $100^{\circ} \mathrm{C}$. Moreover, the second peak of water occurred with a maximum at approx. $330^{\circ} \mathrm{C}$. At this temperature a considerable amounts of $\mathrm{CO}_{2}$ were released also, as reflected on the $\mathrm{m} / \mathrm{e}=44$ mass signal as a large, sharp peak (Fig. 7c). It can be clearly seen that a storage of the cobalt-lanthanum catalyst precursor in a close vessel does not protect this material completely from exposure to ambient conditions. As a result, the sample adsorbed some amount of $\mathrm{H}_{2} \mathrm{O}$, as evidenced by an increase of the intensity of $\mathrm{m} / \mathrm{e}=18$ signal. In turn, a storage of the cobalt-lanthanum catalyst precursor in an open vessel caused a strong adsorption of $\mathrm{H}_{2} \mathrm{O}$ and $\mathrm{CO}_{2}$ from air. As mentioned above, the studied $\mathrm{Co} / \mathrm{La}$ catalyst precursor (after calcination at $500^{\circ} \mathrm{C}$ ) may contain a mixture of $\mathrm{La}_{2} \mathrm{O}_{3}$ and $\mathrm{La}_{2} \mathrm{O}_{2} \mathrm{CO}_{3}$. These phases can easily react with water vapor and carbon dioxide from air. Binding of $\mathrm{CO}_{2}$ by $\mathrm{La}_{2} \mathrm{O}_{3}$ causes the formation of carbonate forms ${ }^{10,11,14}$, which then decompose during heating and give a clear peak on $\mathrm{m} / \mathrm{e}=44$ mass signal (Fig. 7c). In turn, the interaction of $\mathrm{La}_{2} \mathrm{O}_{3}$ with $\mathrm{H}_{2} \mathrm{O}$ leads to the formation of $\mathrm{La}(\mathrm{OH})_{3}$ or $\mathrm{LaO}(\mathrm{OH})$ phases ${ }^{16,29}$, which decompose to lanthanum oxide at approx. $330^{\circ} \mathrm{C}$, as indicated by the additional peak in the mass signal of water (Fig. 7b).

In conclusion, significant changes in the phase composition of cobalt-lanthanum catalyst precursors occur as a result of their contact with ambient conditions. It must be taken into account when these catalytic materials are in practical use. However, it is crucial particularly for the proper interpretation of results of catalyst characterization studies carried out using ex situ techniques.

\section{CONCLUSIONS}

In this study thermal analysis coupled with mass spectrometry (TG-MS) were applied to determine the course of the calcination process of a cobalt-lanthanum catalyst precursor containing a co-precipitated mixture of cobalt and lanthanum compounds. It was stated that the calcination in air at $500^{\circ} \mathrm{C}$ is sufficient to transform a precipitate containing Co compounds into $\mathrm{Co}_{3} \mathrm{O}_{4}$, but it does not lead to a complete decomposition of a precipitate containing La compounds. In order to obtain a cobalt-lanthanum catalyst precursor, containing $\mathrm{Co}_{3} \mathrm{O}_{4}$ and $\mathrm{La}_{2} \mathrm{O}_{3}$, a high-temperature calcination in air (about $800^{\circ} \mathrm{C}$ ) of the obtained co-precipitated mixture is required. However, it causes a deterioration of textural parameters of a catalyst precursor. The storage method has a substantial effect on a composition of the studied $\mathrm{Co} / \mathrm{La}$ catalyst precursor. The storage of this type of precursor in contact with air changes significantly its phase composition by a formation of lanthanum hydroxide and carbonates, which should be taken into account during application of these materials and analysis of their characterization studies results (ex situ measurements in particular).

\section{ACKNOWLEDGMENT}

The research has been funded by The National Centre for Research and Development within The Applied Research Programme according to contract No. PBS2/A1/13/2014.

\section{LITERATURE CITED}

1. Jacobsen, C.J.H. (2000). Novel class of ammonia synthesis catalysts. Chem. Commun. 12, 1057-1058. DOI: 10.1039/ B002930K.

2. Moszyński, D., Jędrzejewski, R., Ziebro, J. \& Arabczyk, W. (2010). Surface and catalytic properties of potassium-modified cobalt molybdenum catalysts for ammonia synthesis. Appl. Surf. Sci. 256(17), 5581-5584. DOI: 10.1016/j.apsusc.2009.12.150.

3. Hagen, S., Barfod, R., Fehrmann, R., Jacobsen, C.J.H., Teunissen, H.T. \& Chorkendorf, I. (2003). Ammonia synthesis 
with barium-promoted iron-cobalt alloys supported on carbon. J. Catal. 214(2), 327-335. DOI: 10.1016/S0021-9517(02)00182-3.

4. Raróg-Pilecka, W., Miśkiewicz, E., Matyszek, M., Kaszkur, Z., Kępiński, L. \& Kowalczyk, Z. (2006). Carbon-supported cobalt catalyst for ammonia synthesis: Effect of preparation procedure. J. Catal. 237(1), 207-210. DOI: 10.1016/j. jcat.2005.10.029.

5. Tarka, A., Zybert, M., Truszkiewicz, E., Mierzwa, B., Kępiński, L., Moszyński, D. \& Raróg-Pilecka, W. (2015). Effect of a barium promoter on the stability and activity of carbon-supported cobalt catalysts for ammonia synthesis. ChemCatChem 7(18), 2836-2839. DOI: 10.1002/cctc.201500309.

6. Karolewska, M., Truszkiewicz, E., Iwanek, E., Mierzwa, B. \& Raróg-Pilecka, W. (2011). Cobalt catalysts doped with cerium and barium obtained by co-precipitation method for ammonia synthesis process. Catal. Lett. 141(5), 678-684. DOI: 10.1007/s10562-011-0564-8.

7. Karolewska, M., Truszkiewicz, E., Mierzwa, B., Kępiński, L. \& Raróg-Pilecka, W. (2012). Ammonia synthesis over cobalt catalysts doped with cerium and barium. Effect of the ceria loading. Appl. Catal. A: General 445-446, 280-286. DOI: 10.1016/j.apcata.2012.08.028.

8. Zybert, M., Karasińska, M., Truszkiewicz, E., Mierzwa, B. \& Raróg-Pilecka, W. (2015). Properties and activity of the cobalt catalysts for $\mathrm{NH}_{3}$ synthesis obtained by co-precipitation the effect of lanthanum addition. Pol. J. Chem. Technol. 17(1), 138-143. DOI: 10.1515/pjct-2015-0020.

9. Zybert, M., Tarka, A., Mierzwa, B., Kępiński, L. \& Raróg-Pilecka, W. (2016). Promotion effect of lanthanum on the $\mathrm{Co} / \mathrm{La} / \mathrm{Ba}$ ammonia synthesis catalysts - the influence of lanthanum content. Appl. Catal. A: General 515, 16-24. DOI: 10.1016/j.apcata.2016.01.036.

10. Klingenberg, B. \& Vannice, M.A. (1996). Influence of pretreatment on lanthanum nitrate, carbonate and oxide powders. Chem. Mater. 8(12), 2755-2768. DOI: 10.1021/cm9602555.

11. Wang, X., Wang, M., Song, H. \& Ding, B. (2006). A simple sol-gel technique for preparing lanthanum oxide nanopowders. Mater. Lett. 60(17-18), 2261-2265. DOI: 10.1016/j. matlet.2005.12.142.

12. Wendlandt, W.W. (1956). The thermolysis of the rare earth and other metal nitrates. Anal. Chim. Acta 15, 435-439. DOI: 10.1016/0003-2670(56)80082-2.

13. Patil, K.C., Gosavi, R.K. \& Rao, C.N.R. (1967). Infrared spectra and thermal decomposition of metal nitrites and nitrates. Inorg. Chim. Acta 1, 155-160. DOI: 10.1016/S00201693(00)93160-8.

14. Shirsat, A.N., Ali, M., Kaimal, K.N.G., Bharadwaj, S.R. \& Das, D. (2003). Thermochemistry of $\mathrm{La}_{2} \mathrm{O}_{2} \mathrm{CO}_{3}$ decomposition. Thermochim. Acta 399(1-2), 167-170. DOI: 10.1016/ S0040-6031(02)00459-8.

15. Turcotte, R.P., Sawyer, J.O. \& Eyring, L. (1969). Rare earth dioxymonocarbonates and their decomposition. Inorg. Chem. 8(2), 238-246. DOI: 10.1021/ic50072a012.

16. Walter, D. (2006). Kinetic Analysis of the transformation from lanthanum hydroxide to lanthanum oxide. Z. Anorg. Allg. Chem. 632(12-13), 2165. DOI: 10.1002/zaac.200670177.

17. Füglein, E. \& Walter, D. (2012). Thermal analysis of lanthanum hydroxide. J. Therm. Anal. Calorim. 110(1), 199-202. DOI: $10.1007 / \mathrm{s} 10973-012-2298-2$.

18. Dollimore, D. (1981). The use of thermal analysis in studying catalysts and the chemisorption process. Thermochim. Acta 50(1-3), 123-146. DOI: 10.1016/0040-6031(81)85050-2.

19. Janssen, F. (1986). The use of thermal analysis techniques in heterogeneous catalysts. Thermochim. Acta 148, 137-147. DOI: 10.1016/0040-6031(89)85210-4.

20. Leofanti, G., Tazzola, G., Padovan, M., Petrini, G., Bordiga, S. \& Zecchina, A. (1997). Catalyst characterization: applications. Catal. Today 34(3-4), 329-352. DOI: 10.1016/ S0920-5861(97)86089-0.
21. Auroux, A. (1994). Thermal methods: calorimetry, differential thermal analysis and thermogravimetry. In B. Imelik \& J.C. Vedrine (Eds.), Catal. Character. Phys. Techniq. Solid Mater. (pp. 611-650). New York, Springer Science + Business Media.

22. Zybert, M., Truszkiewicz, E., Mierzwa, B. \& Raróg-Pilecka, W. (2014). Thermal analysis coupled with mass spectrometry as a tool to determine the cobalt content in cobalt catalyst precursors obtained by co-precipitation. Thermochim. Acta 584, 31-35. DOI: 10.1016/j.tca.2014.03.026.

23. Lendzion-Bieluń. Z., Jędrzejewski, R. \& Arabczyk, W. (2011). The effect of aluminum oxide on the reduction of cobalt oxide and thermostability of cobalt and cobalt oxide. Cent. Eur. J. Chem. 9(5), 834-839. DOI: 10.2478/s11532-011-0059-x.

24. El-Shobaky, G.A., Ahmad, A.S., Al-Noaimi, A.N. \& El-Shobaky, H.G. (1996). Thermal decomposition of basic cobalt and copper carbonates. J. Therm. Anal. 46(6), 1801-1808. DOI: 10.1007/BF01980784.

25. El-Shobaky, G.A., Hewaidy, I.F. \& El-Nabarawy, T. (1980). A study of the influence of thermal treatment of the catalyst on the catalytic oxidation of $\mathrm{CO}$ on $\mathrm{Co}_{3} \mathrm{O}_{4}$. Surf. Technol. 10(4), 311-319. DOI: 10.1016/0376-4583(80)90088-6.

26. Mentus, S., Jelić, D. \& Grudić, V. (2007). Lanthanum nitrate decomposition by both temperature programmed heating and citrate gel combustion. J. Therm. Anal. Calorim. 90(2), 393-397. DOI: 10.1007/s10973-006-7603-5.

27. Karolewska, M., Wójcik, P., Truszkiewicz, E., Narowski, R. \& Raróg-Pilecka, W. (2012). Co-precipitation as an effective method for preparation of cobalt catalysts for ammonia synthesis. Przem. Chem. 91(11), 2142-2145 [in Polish].

28. Zybert, M. (2015). Preparation, properties and activity of the promoted cobalt catalysts for ammonia synthesis. Doctoral dissertation, Warsaw University of Technology, Warsaw [in Polish].

29. Neumann, A. \& Walter, D. (2006). The thermal transformation from lanthanum hydroxide to lanthanum hydroxide oxide. Thermochim. Acta 445(2), 200-204. DOI: 10.1016/j. tca.2005.06.013. 